\title{
Varroa destructor and viruses association in honey bee colonies under different climatic conditions
}

\author{
Agostina Giacobino, ${ }^{1 *}$ Ana I. Molineri, ${ }^{1}$ \\ Adriana Pacini, ${ }^{1}$ Norberto Fondevila, ${ }^{2}$ \\ Hernán Pietronave, ${ }^{3}$ Graciela Rodríguez, ${ }^{4}$ \\ Alejandra Palacio, ${ }^{5}$ Natalia Bulacio Cagnolo, ${ }^{1}$ \\ Emanuel Orellano, ${ }^{1}$ César E. Salto, ${ }^{1}$ \\ Marcelo L. Signorini ${ }^{1}$ and Julieta Merke ${ }^{1}$ \\ ${ }^{1}$ Consejo Nacional de Investigaciones Científicas y \\ Técnicas, Instituto Nacional de Tecnología \\ Agropecuaria EEA Rafaela, Ruta $34 \mathrm{Km}$ 227, Rafaela, \\ 2300, Provincia de Santa Fe, Argentina. \\ 2 Instituto de Virología del Centro de Investigación en \\ Ciencias Veterinarias y Agronómicas del Instituto \\ Nacional de Tecnología Agropecuaria, Repetto y de los \\ Reseros s/n 1686, Hurlingham (Buenos Aires), \\ Argentina. \\ 3 Instituto Nacional de Tecnología Agropecuaria EEA \\ Reconquista, Ruta $11 \mathrm{Km}$ 773, 3567, Reconquista \\ (Santa Fe), Argentina. \\ ${ }^{4}$ Instituto Nacional de Tecnología Agropecuaria EEA \\ Hilario Ascasubi, Ruta Nacional $3 \mathrm{Km} 794,8142$, Hilario \\ Ascasubi (Buenos Aires), Argentina. \\ 5 Instituto Nacional de Tecnología Agropecuaria EEA \\ Balcarce, Ruta $226 \mathrm{Km}$ 73,5, 7620, Balcarce (Buenos \\ Aires), Argentina.
}

\section{Summary}

Honey bee colonies are threatened by multiple factors including complex interactions between environmental and diseases such as parasitic mites and viruses. We compared the presence of honeybeepathogenic viruses and Varroa infestation rate in four apiaries: commercial colonies that received treatment against Varroa and non-treated colonies that did not received any treatment for the last 4 years located in temperate and subtropical climate. In addition, we evaluated the effect of climate and Varroa treatment on deformed wing virus (DWV) amounts. In both climates, DWV was the most prevalent virus, being the only present virus in subtropical colonies. Moreover, colonies from subtropical climate also showed

Received 0 Month, 0000; revised 0 Month, 0000; accepted 0 Month, 0000. *For correspondence. E-mail agostinagiacobino@ hotmail.com; giacobino.agostina@ inta.gob.ar. Tel. +54 3492 440121; Fax +54 3492440114 . reduced DWV amounts and lower Varroa infestation rates than colonies from temperate climate. Nevertheless, non-treated colonies in both climate conditions are able to survive several years. Environment appears as a key factor interacting with local bee populations and influencing colony survival beyond Varroa and virus presence.

\section{Introduction}

Apis mellifera plays an important role in global economy as honey producer and as the main pollinator of food crops (Decourtye et al., 2010). Honey bee colonies are threatened by a wide variety of diseases and parasites, including bee pathogenic viruses (Brutscher et al., 2015). Growing attention is being paid to viruses infection since the increased number of colony losses seems to be explained by a combination of variables including co-infections with Varroa destructor (Genersch and Aubert, 2010; Francis et al., 2013). Viruses differ in their geographical distribution (De Miranda et al., 2010; Genersch and Aubert, 2010). Primarily, deformed wing virus (DWV) is globally distributed (De Miranda and Genersch, 2010) and its presence was linked to colonies losses (Francis et al., 2013). Acute bee paralysis virus (ABPV) was linked to colony loses in Europe while the Israeli acute paralysis virus (IAPV), and Kashmir Bee Virus (KBV) were proposed as the causes of colony losses in United States (Genersch and Aubert, 2010). Together with these viruses, chronic bee paralysis virus (CBPV), black queen cell virus (BQCV) and sacbrood virus (SBV) were also detected in Argentina (Reynaldi et al., 2010; 2011; Castilla et al., 2015). On the contrary, the Kashmir bee virus (KBV) has been detected mostly in North America and New Zealand (De Miranda et al., 2010) but so far no detection has been reported in Argentina or other countries from South America (Antúnez et al., 2006; Teixeira et al., 2008; Reynaldi et al., 2010; 2011).

Varroa destructor plays an important role in the transmission and virulence of DWV. The mite causes a suppression of the immunocompetence of the host, giving to this virus the opportunity to infect bees (Yang and Cox-Foster, 2005). Besides, chemical treatment not only directly affects the immunity of the honey bees (Boncristiani et al., 2012; Locke et al., 2012) but also has an 
important influence on parasite-host relationship. Active Varroa control by beekeepers would disrupt any association between Varroa infestation rates and the virus epidemics (Mondet et al., 2014).

Abrupt losses may occur triggered by the combination of these diseases with environmental factors such as climate conditions. Colony life histories including Varroa management, related to brood-free periods during periods without flowering, have a significant influence on Varroa infestation rates and consequently can affect associated virus presence or distribution (Meixner et al., 2015).

The objective of this study was to evaluate the effect of climate and Varroa mites treatment on the prevalence of the main viruses present in honey bee colonies from Argentina.

\section{Materials and methods}

The presence of seven virus species (DWV, ABPV, CBPV, BQCV, KBV, IAPV and SBV) was evaluated in 25 colonies distributed in two different climatic conditions from Argentina: 13 in the subtropical climate and 12 in the temperate climate. In each climate, there were also compared Varroa infestation and viruses prevalence between commercial colonies (six per climate) that received annual treatment against Varroa mites ('Treated colonies' from now on) and 'non-treated' colonies (six in temperate and seven in subtropical) that did not received any treatment against Varroa mites. These non-treated colonies were set up in 2011 from brood nuclei and selected queens from a network of evaluation of honeybee stocks for Varroa tolerance (Merke et al., 2014a). This network is funded by the Beekeeping Program from the National Institute for Agricultural Technology (PROAPI-INTA) and it was originated from the genetic improvement program for honey bee brood diseases (Palacio et al., 2000; 2003; 2012). Since 2007, this program had been also selecting colonies with Varroa tolerant traits following the same breeding protocol. Queen selection and stock reproduction was based on the capacity of the colonies to reduce Varroa population growth, either by defensive behaviour or mite reproduction interruption under different climate conditions (Merke et al., 2014b). All samples were taken from asymptomatic colonies just before beekeepers applied the Varroa treatments to the treated colonies group at the beginning of autumn 2015 (late March).

The subtropical climate colonies were located in a region with annual mean temperature of $19.9^{\circ} \mathrm{C}$ (max: $25.9^{\circ} \mathrm{C}$ and $\min : 14.5^{\circ} \mathrm{C}$ ) and mean annual precipitations of $1408 \mathrm{~mm}\left(29^{\circ} 14^{\prime} 00^{\prime \prime} \mathrm{S} 59^{\circ} 56^{\prime} 00^{\prime \prime} \mathrm{W}\right)$. The most relevant production is intensive livestock (dairy farms and wintering animals on alfalfa-based pastures) combined with sunflower, sugar cane and cotton crops and natural forest. Temperate climate colonies were located in a region with annual mean temperature of $18^{\circ} \mathrm{C}$ (max: $25^{\circ} \mathrm{C}$ and $\min : 12.1^{\circ} \mathrm{C}$ ), with average annual precipitations under $800 \mathrm{~mm}\left(31^{\circ} 16^{\prime} 00^{\prime \prime} \mathrm{S} 61^{\circ} 29^{\prime} 00^{\prime \prime} \mathrm{W}\right)$. The most relevant production is also intensive livestock but it is combined with agriculture production based on extensive soya, wheat, and corn crops (Giorgi et al., 2008).

\section{Sampling and virus analysis}

About 40 worker bees were collected alive from the central frames of the brood chamber in each colony. Samples were immediately freezer frozen (within $2 \mathrm{~h}$ ) and sent to the laboratory where they were macerated in mortar and homogenized with $7 \mathrm{ml}$ of $\mathrm{pH} 7$ phosphate buffer (PBS). The mixture was centrifuged at $4500 \mathrm{rpm}$ at $8^{\circ} \mathrm{C}$ for $45 \mathrm{~min}$ and the supernatant was collected and stored at $-20^{\circ} \mathrm{C}$.

Pools of 30 bees were homogenized in $15 \mathrm{ml}$ PBS and total RNA was extracted using TRIzol ${ }^{\circledR}$ Reagent (Invitrogen) following the manufacturer recommendation. RNA samples were dissolved in 10-50 $\mu$ ultra-pure water (Distilled Water DNAse, RNAse Free; Invitrogen).

Real Time PCR (RT-qPCR) was carried out to determine the presence of DWV, BQCV, ABPV, CBPV, IAPV and KBV. Copy DNA was synthesized by reverse transcription reaction from the extracted RNA. The reaction mixture contained $1 \mu$ l of RNA, $1 \mu$ l of reaction buffer $5 x$ (Promega), $0.5 \mu \mathrm{ldNTP} 10 \mathrm{mM}$ (Promega), $0.125 \mu \mathrm{l}$ of ARNsin $40 \mathrm{U} / \mu \mathrm{l}$ (Promega), $0.25 \mu \mathrm{l}$ of random primers 2 $\mu \mathrm{g} / \mu \mathrm{l}, 0.175 \mu \mathrm{l}$ of reverse transcriptase $200 \mathrm{U} / \mu \mathrm{l}$ (Promega) and completed with volume of $1.95 \mu$ of ultra-pure water (Distilled Water DNAse, RNAse Free; Invitrogen) to obtain a total volume of $5 \mu$ of mixture. The reaction was developed in a Biometra Trio-Thermoblock. The thermal cycling profiles were: $42^{\circ} \mathrm{C}$ for $45 \mathrm{~min}, 94^{\circ} \mathrm{C}$ for $10 \mathrm{~min}$ and $4^{\circ} \mathrm{C}$ for $4 \mathrm{~min}$.

For the RT-PCR amplification, the reaction mixture contained $0.4 \mu \mathrm{l} 1.5 \mathrm{uM}$ of each pair of primers selected and described by Locke et al. (2012), $2.5 \mu$ l Master mix SYBER green PCR kit QuantiTect (cat 204143), $1.45 \mu \mathrm{l}$ ultra-pure water (Distilled Water DNAse, RNAse Free; Invitrogen) and 0,5 $\mu \mathrm{l}$ of cDNA. Samples were amplified using the LightCycler 2.0 Roche Thermocycler with the following thermal cycling profiles: $95^{\circ} \mathrm{C}$ for $10 \mathrm{~min}, 45$ cycles at $95^{\circ}$ for $15 \mathrm{~s}$ and $56^{\circ} \mathrm{C}$ for $1 \mathrm{~min}$. The fluorescence emission of the samples was performed at $530 \mathrm{~nm}$. Samples having a geometric increase in fluorescence emission in the two previous successive cycles of cycling number 45 were considered positive. It was considered the first of these emission lifting cycles as first cycle of positivity. Negative $\left(\mathrm{H}_{2} \mathrm{O}\right)$ and positive control (recombinant plasmid DNA with virus insert into 
pGEM-T Easy vector) were included in each run of the RT-PCR reaction. Quantification of DWV was performed by RT-qPCR with the reference gene DWVgp1 according to Chen et al. (2005). The estimation of the viral loads of positive samples was performed using standard curves prepared with threshold cycle (Ct) data obtained for known concentrations of cDNA fragments copies of the virus studied.

\section{Sampling and Varroa analysis}

Adult bees were examined to diagnose the presence of Varroa mites in all tested colonies. Approximately 250 bees per colony were collected from both sides of three unsealed brood combs in a jar containing $50 \%$ ethanol. The mites were separated from the bees by pouring the jar content into a sieve with a $2 \mathrm{~mm}$ mesh size (Dietemann et al., 2013). The intensity of mite infestation on adult bees was calculated dividing the number of mites counted by the number of bees in the sample to determine the proportion of infested individuals and multiplying by 100 to obtain the infestation rate per colony (Dietemann et al., 2013). In addition, the number of adult bees and number of cells with pollen and honey reserves of all colonies were estimated according to the Liebefeld method (Imdorf and Gerig, 2001).

\section{Statistical analysis}

Only DWV amounts were statistically assessed as it was the most prevalent virus and was found in all groups. The mite infestation rate and DWV amounts between subtropical and temperate climate and between treated and non-treated colonies were compared using a $T$ student-test. DWV amounts was analysed with full factorial ANCOVA using climate (subtropical/temperate) and Varroa treatment (yes/no) as fixed factors and mite infestation rate as covariate. Since is not possible to log transform zero values, the response variable was $\log _{10}$ of (DWV copies +1$)$ in order to include all values (negative and positive samples).

\section{Results and discussion}

In both climate DWV was the most prevalent virus being present in 3 of 13 and 12 of 12 colonies in subtropical and temperate climate, respectively $(P<0.0001)$. Colonies from subtropical climate showed only infections with DWV. On the contrary, in temperate climate 3 of 12 of the colonies had co-infection with BQCV and 3 of 12 with ABPV. Similarly, 1 of 12 colonies had been coinfected with CBPV and 1 of 12 with SBV also in colonies from temperate climate. No colonies tested positive for KBV or IAPV. Both treated and untreated colonies from temperate climate had co-infections. Colonies from temperate climate presented higher infestation rate with
Varroa mites $(9.32 \% \pm 8.55 \%)$ than subtropical colonies $(2.49 \% \pm 2.54 \%)(t=2.75 ; P=0.01)$. Varroa infestation rate was higher in treated than in non-treated colonies from subtropical climate $(t=-2.97 ; P=0.01)$ while it was similar in both groups from temperate climate $(t=-0.67 ; P=0.52)$. Mean mite infestation rate in colonies without virus was $2.04 \% \pm 1.99 \%$, while colonies with single DWV infection had $7.39 \% \pm 4.29 \%$ and colonies with co-infected DWV had $9.02 \% \pm 10.59 \%$ $(F=2.85 ; P=0.07)$. No differences were found in mite infestation rate between colonies with and without the other detected viruses. Also, adult bee population and honey reserves were similar in all groups $(F:$ 1.059; $P=0.39$ and $F: 0.36 ; P=0.783$, respectively). On the other hand, pollen cells in treated and non-treated colonies from temperate climate were significantly lower than pollen cells from the subtropical climate colonies ( $F: 6.9 ; P=0.002$ ).

The presence of BQCV, DWV CBPV, SBV and ABPV has been previously reported in Uruguay (Antúnez et al., 2005; 2006); Brazil (Teixeira et al., 2008) and Argentina (Reynaldi et al., 2010). With the exception of DWV, viruses prevalence reported here were similar to preceding reports in Argentina (Castilla et al., 2015) and lower than Viruses prevalence in France (Tentcheva et al., 2004), Denmark (Francis et al., 2013) and Uruguay (Antúnez et al., 2006). Previous studies also reported the presence of IAPV in Argentina (Reynaldi et al., 2011; Castilla et al., 2015) although samples from both climates in this study were not infected with this virus or with $\mathrm{KBV}$.

High prevalence and more species diversity were found in both groups of colonies from temperate climate suggesting an influence on infection prevalence (Meixner et al., 2014). As temperate colonies showed also higher infestation rate with Varroa mites than subtropical colonies, it seems possible that it favours the occurrence of more than one virus species simultaneously. Mondet et al. (2014) suggested that the presence of Varroa increases the number of viruses that can be detected in a colony. Co-infection of DWV with other species occurred when varroa infestation was over $9 \%$. Varroa mites are associated to ABPV and DWV occurrence (Ball and Allen, 1988; Bowen-Walker et al., 1999; Chen and Siede, 2007) but transmission of BQCV and CBPV by varroa mites appears to be less probable (Tentcheva et al., 2004; Chen and Siede, 2007). Nevertheless, viruses whose active transmission by Varroa is less certain still may benefit from Varroa weakened colonies (Mondet et al., 2014; Amiri et al., 2015).

Colonies from temperate climate showed higher DWV amounts compared with subtropical climate $(t=6.86$; $P<0.0001$ ); (Fig. 1). Similar DWV amounts was found between treated and non-treated colonies from 


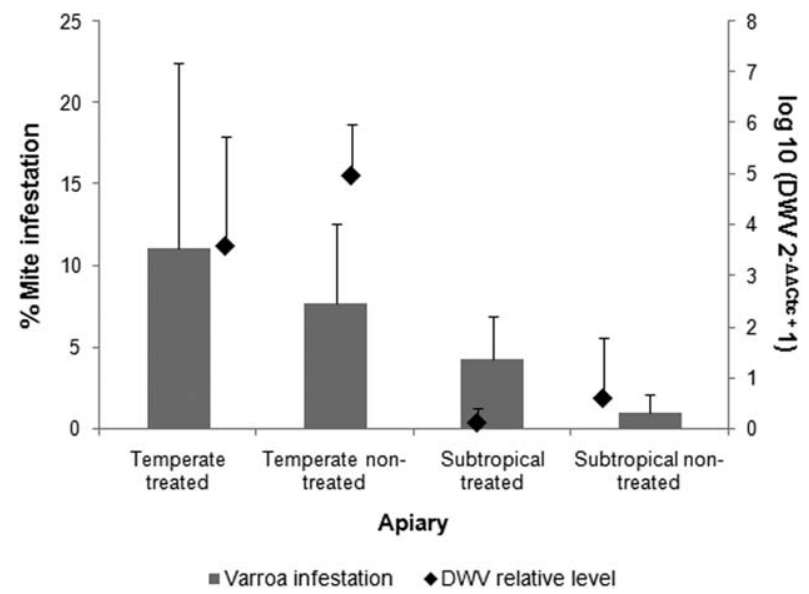

Fig. 1. Deformed wing virus relative virus level and mite infestation rate in honey bee colonies treated and non-treated against Varroa destructor from temperate and subtropical climate.

Table 1. Full factorial ANCOVA for Deformed Wing Virus (DWV) amounts in temperate and subtropical climate for honey bee colonies with and without annual treatment against Varroa destructor.

\begin{tabular}{lccc}
\hline & $\mathrm{F}$ & $\mathrm{df}$ & $P$-value \\
\hline Model intercept & 25.62 & 1 & $<0.001$ \\
Climate & 32.74 & 1 & $<0.001$ \\
Varroa treatment & 4.57 & 1 & $\mathbf{0 . 0 4 5}$ \\
Climate x Varroa treatment & 0.76 & 1 & 0.39 \\
Varroa infestation rate (covariate) & 2.27 & 1 & 0.15 \\
\hline
\end{tabular}

Levene's test F: $2.71 ; \mathrm{P}=0.07$.

temperate climate $(t=1.41 ; P=0.19)$ and from subtropical climate $(t=0.96 ; P=0.36)$. DWV amounts in the autumn of 2015 were significantly influenced by climate and secondarily by the treatment against Varroa mites (Table 1).

Deformed Wing Virus appears to be the most prevalent virus in honey bee colonies from Argentina independently of the climate. As in previous studies, DWV was more common than other viruses such as ABPV (Tentcheva et al., 2004; Meixner et al., 2014). However, there were noticeable differences in DWV prevalence and amounts as well as in Varroa infestation rates in temperate and subtropical colonies (Lodesani et al., 2014; Meixner et al., 2014). One possible explanation may be related to a better nutritional source provided by subtropical climate as the pollen reserves in these colonies were significantly higher than in temperate colonies. As previously reported, nutritional status has an outstanding impact on colony health (Alaux et al., 2010; Giacobino et al., 2014; DeGrandi-Hoffman et al., 2016). When climate is included in the analysis, we found a less significant contribution of the autumn infestation level of Varroa mites to DWV amounts (Meixner et al., 2014). Environmental factors, particularly climate and landscape may play a key role in mediating the hostparasite interaction, and perhaps honey bee health in general (Muli et al., 2014).

DWV is known to be associated with Varroa destructor and has been detected in the mites (Genersch and Aubert, 2010). Heavy infestation during winter of either Varroa mites or DWV spread by the mite has been shown to be highly predictive of colony failure (Dainat et al., 2012). The lower infestation registered in subtropical climate may explain partially the differences in DWV amounts between geographical zones. At the same time, these differences in Varroa infestation may be supported by a higher impact of the Africanized bees in subtropical colonies (Sheppard et al., 1991; Rosenkranz, 1999) as honey bee race play a crucial role in resistance to Varroa (Camazine, 1986). Recently, Straus et al. (2015) showed that colonies of $A$. mellifera scutellata that did not present any signs of disease or collapse and were developing normally in the presence of Varroa mites. Similarly, new parasites and pathogens invading honey bee populations in East Africa seem no to directly impacted on Kenyan bee populations (Muli et al., 2014). More accurately, the lower Varroa levels in colonies from subtropical zone could be explained by the fact that Africanized bees in South America have higher levels of hygienic behaviour, higher levels of grooming mites off of adult bees and lower levels of mite reproduction on pupae than European bees (Camazine, 1986; GuzmanNovoa et al., 1999). However, although they were not part of this study, previous results obtained in these apiaries showed that the proportion of Africanized bees in both places was similar (J. Merke, pers. comm.).

Climate type had a highly significant influence on the mite infestations and apparently may be more important than race (Moretto et al., 1991). Climate effect on the number of Varroa mites might be explained by longer brood presence, however regardless of the temperate climate in most regions from Argentina there is no broodless period (Marcangeli et al., 1992; Giacobino et al., 2015). Yet, assuming that bees from subtropical climate had, in fact, a relative longer season with brood and consequently higher mite populations than colonies in temperate climate (Vetharaniam, 2012), this does not explain why treated and non-treated colonies from subtropical climate presented similar DWV relative virus levels.

The non-treated colonies, for which yearly treatment is not required, were selected for their capacity to limited Varroa population growth and therefore it was expected to have lower Varroa infestation rate than treated colonies (Francis et al., 2013; Merke et al., 2014b). Moreover, treated and non-treated colonies from subtropical climate differed significantly in their Varroa infestation rate but DWV relative virus levels were similar in both 
groups. On the contrary, Varroa infestation rate and DWV amounts were similar between both groups in temperate climate. It seems that environmental condition might influence colony-specific epidemic factors, so they can exhibit low levels of DWV even with significant Varroa infestation rates, and vice versa (Mondet et al., 2014).

Non-treated colonies from temperate climate showed the highest Varroa infestation rate and DWV relative virus levels but however had survived for the last 4 years. Climatic and other environmental conditions have been demonstrated to influence on the mite infestation level a colony is able to tolerate (Meixner et al., 2014) and therefore to affect the probability of colony survival under multiples stress factor such as co-occurrence with virus species. For instance, it was mentioned before the relationship between climate conditions, bee race and Varroa mite levels (Camazine 1986; Moretto et al., 1991).

Colonies from subtropical climate showed reduced virus prevalence and DWV amounts together with lower Varroa infestation rates compared to colonies from temperate climate, independently of Varroa control management. However, non-treated colonies are able to survive several years under different stress level in both climate conditions, probably because local populations of bees show better survival in the presence of pathogens than introduced bees (Meixner et al., 2015). Environment appears as a key factor interacting with local bee populations and influencing colony survival beyond Varroa and Virus presence.

\section{Acknowledgements}

This study has been carried out with the financial support of the PNAPI Project N ${ }^{\circ} 1112042$ and Specific Project № 1112042 'Estrategias multidisciplinarias para mitigar el efecto del nuevo contexto ambiental y productivo sobre la colmena', Instituto Nacional de Tecnología Agropecuaria. Agostina Giacobino, Ana Molineri and Adriana Pacini are doctoral fellows from the Consejo Nacional de Investigaciones Científicas y Técnicas (CONICET, Argentina). Marcelo L. Signorini is a Research Career Member from the Consejo Nacional de Investigaciones Científicas y Técnicas (CONICET, Argentina)

\section{References}

Alaux, C., Ducloz, F., Craucer, D., and Le Conte, Y. (2010) Diet effects on honeybee immunocompetence. Biol Lett 6: $562-565$.

Amiri, E., Meixner, M., Nielsen, S.L., and Kryger, P. (2015) Four categories of viral infection describe the health status of honey bee colonies. PLoS One 10 (10): e0140272. doi:10.1371/journal.pone.0140272.

Antúnez, K., D'Alessandro, B., Corbella, P., and Zunino, A. (2005) Detection of chronic bee paralysis virus and acute bee paralysis virus in Uruguayan honeybees. $J$ Invertebr Pathol 90: 69-72.
Antúnez, K., D’Alessandro, B., Corbella, P., Ramallo, G., and Zunino, A. (2006) Honeybee viruses in Uruguay. $J$ Invertebr Pathol 93: 67-70.

Ball, B.V., and Allen, M.F. (1988) The prevalence of pathogens in honey bee (Apis mellifera) colonies infested with the parasitic mite Varroa jacobsoni. Ann Appl Biol 113 (2): 237-244.

Boncristiani, H., Underwood, R., Schwarz, R., Evans, J.D., Pettis, J., and van Engelsdorp, D. (2012) Direct effect of acaricides on pathogen loads and gene expression levels in honey bees Apis mellifera. J Insect Physiol 58: 613-620.

Bowen-Walker, P.L., Martin, S.J., and Gunn, A. (1999) The transmission of deformed wing virus between honeybees (Apis mellifera L.) by the ectoparasitic mite Varroa jacobsoni Oud. J Invertebr Pathol 73 (1): 101-106.

Brutscher, L.M., Daughenbaugh, K.F., and Flenniken, M.L. (2015) Antiviral defense mechanisms in honey bees. Curr Opin Insect Sci 10: 71-82.

Camazine, S. (1986) Differential reproduction of the mite, Varroa jacobsoni (Mesostigmata: Varroidae), on Africanized and European honey bees (Hymenoptera: Apidae). Ann Entomol Soc Am 79: 801-803.

Castilla, R., Reynaldi, F.J., Sguazza, G.H., Pecoraro, M.R., and Galosi, C.M. (2015) Detección de virus que afectan a las abejas durante el periodo 2009-2014. Buenos Aires, Argentina: XI Congreso Argentino de Virología and II Congreso Latinoamericano de Virología. 23-26 of June. abstracts book page 116 .

Chen, Y.P., and Siede, R. (2007) Honey bee viruses. Adv Virus Res 70: 33-80.

Chen, Y.P., Higgins, J.A., and Feldlaufer, M.F. (2005) Quantitative real-time reverse transcription-PCR analysis of deformed wing virus infection in the honeybee (Apis mellifera L.). Appl Env Microbiol 71: 436-441.

Dainat, B., Evans, J.D., Chen, Y.P., Gauthier, L., and Neumann, P. (2012) Dead or alive: deformed wing virus and Varroa destructor reduce the life span of winter honeybees. Appl Environ Microbiol 78: 981-987.

Decourtye, A., Mader, E., and Desneux, N. (2010) Landscape enhancement of floral resources for honey bees in Agro-ecosystems. Apidologie 41: 264-277.

DeGrandi-Hoffman, G., Chen, Y., Rivera, R., Carroll, M., Chambers, M., Hidalgo, G., and Watkins de Jong, E. (2016) Honey bee colonies provided with natural forage have lower pathogen loads and higher overwinter survival than those fed protein supplements. Apidologie 47: 186-196.

De Miranda, J., and Genersch, E. (2010) Deformed wing virus. J Invertebr Pathol 103: S48-S61.

De Miranda, J., Cordoni, G., and Budge, G. (2010) The acute bee paralysis virus - Kashmir bee virus - Israeli acute paralysis virus complex. J Invertebr Pathol 103: 30-47.

Dietemann, V., Nazzi, F., Martin, S.J., Anderson, D.L., Locke, B., Delaplane, K.S., et al. (2013) Standard methods for varroa research. In The COLOSS BEEBOOK, Vol. II: Standard Methods for Apis mellifera Pest and Pathogen Research. Dietemann, V., Ellis, J.D., and Neumann, P., (eds). J Apic Res 52 (1). http://dx.doi.org/10. 3896/IBRA.1.52.1.09.

Francis, R.M., Nielsen, S.L., and Kryger, P. (2013) Varroavirus interaction in collapsing honey bee colonies. PLoS One 8 (3): e57540. doi:10.1371/journal.pone.0057540. 
Genersch, E., and Aubert, M. (2010) Emerging and reemerging viruses of the honey bee (Apis mellifera L.). Vet Res 41 (6): 54. doi:10.1051/vetres/2010027.

Giacobino, A., Bulacio Cagnolo, N., Merke, J., Orellano, E., Bertozzi, E., Masciangelo, G., et al. (2014) Risk factors associated with the presence of Varroa destructor in honey bee colonies from east-central Argentina. Prev Vet Med 115: 280-287.

Giacobino, A., Bulacio Cagnolo, N., Merke, J., Orellano, E., Bertozzi, E., Masciangelo, G., et al. (2015) Risk factors associated with failures of Varroa treatments in honey bee colonies without broodless period. Apidologie 46: 573-582.

Giorgi, R., Tosolini, R., Sapino, V., Villar, J., León, C., and Chiavassa, A. (2008) Zonificación Agroeconómica de la provincia de Santa Fe. In INTA (eds) 110, ISSN 03259137, Rafaela, Santa Fe, Argentina, pp. 215-224.

Guzman-Novoa, E., Vandame, R., and Arechavaleta, M.E. (1999) Susceptibility of European and Africanized honey bees (Apis mellifera L.) to Varroa jacobsoni Oud. in Mexico. Apidologie 30: 173-182.

Imdorf, A., and Gerig, L. (2001) Course in determination of colony strength. Swiss Federal Dairy Research Institute, Liebefeld CH 3003 Bern Switzerland (after L Gerig, 1983. Lehrgang zur Erfassung der Volksstärke). Schweiz BienenZeitung 106: 199204.

Locke, B., Forsgren, E., Fries, I., and De Miranda, J.R. (2012) Acaricide treatment affects viral dynamics in Varroa destructor-infested honey bee colonies via both host physiology and mite control. Appl Environ Microbiol 78: 227-235. doi:10.1128/AEM.06094-11.

Lodesani, M., Costa, C., Besana, A., Dall'Olio, R., Franceschetti, S., Tesoriero, D., and Vaccari, G. (2014) Impact of control strategies for Varroa destructor on colony survival and health in northern and central regions of Italy. J Apicult Res 53 (1): 155-164.

Marcangeli, J.A., Eguaras, M.J., and Fernandez, N.A. (1992) Reproduction of Varroa jacobsoni (Acari: Mesostigmata: Varroidae) in temperate climates of Argentina. Apidologie 23: 57-60.

Meixner, M.D., Francis, R.M., Gajda, A., Kryger, P., Andonov, S., Uzunov, A., et al. (2014) Occurrence of parasites and pathogens in honey bee colonies used in a European genotype-environment interactions experiment. J Apicult Res 53 (2): 215-229. doi:10.3896/IBRA.1.53.2.04.

Meixner, M.D., Kryger, P., and Costa, C. (2015) Effects of genotype, environment, and their interactions on honey bee health in Europe. Curr Opin Insect Sci 10: 177-184.

Merke, J., Lanzavecchia, S., Garcia Paoloni, S., Pietronave, H., Fain, H., Agra, M., et al. (2014a) Varroa infestation and presence of viruses in honeybees colonies without Varroosis treatment, in temperate and subtropical climates in Argentina. In Proceedings of the 6th European Conference of Apidology - EURBEE 6, 9-12 September, Murcia, Spain.

Merke, J., Rodriguez, G., Lanzavecchia, S., García Paoloni, S., Pietronave, H., Fain, H., et al. (2014b) Red Nacional de apiarios de tolerancia en Argentina. XI Congreso Latinoamericano de Apicultura FILAPI. From september 3-6 in Misiones Argentina.
Mondet, F., de Miranda, J.R., Kretzschmar, A., Le Conte, Y., and Mercer, A.R. (2014) On the front line: quantitative virus dynamics in honeybee (Apis mellifera L.) colonies along a new expansion front of the parasite Varroa destructor. PLoS Pathog 10 (8): e1004323. doi:10.1371/ journal.ppat.1004323.

Moretto, G., Gonçalves, L.S., De Jong, D., and Bichuette, M.Z. (1991) The effects of climate and bee race on Varroa jacobsoni Oud infestations in Brazil. Apidologie 22: 197-203.

Muli, E., Patch, H., Frazier, M., Frazier, J., Torto, B., Baumgarten, T., et al. (2014) Evaluation of the distribution and impacts of parasites, pathogens, and pesticides on honey Bee (Apis mellifera) populations in East Africa. PLoS One 9 (4): e94459. doi:10.1371/journal.pone.0094459.

Palacio, M.A., Figini, E., Rodriguez, E., Ruffinengo, S., Bedascarrasbure, E., and del Hoyo, M. (2000) Changes in a population of Apis mellifera selected for its hygienic behavior. Apidologie 31: 471-478.

Palacio, M.A., Figini, E., Andere, C., and Bedascarrasbure, E. (2003) Programa de mejoramiento genético, Material Vivo de Calidad. Rev IDIA XXI: 28-31.

Palacio, M.A., Lanzavecchia, S., Merke, J., Agra, M., Martinez, A., Camacho, B., et al. (2012) Evaluation of honey bee stocks for varroa tolerance in Argentina. In Proceedings of the 5th European Conference of Apidology-EURBEE 5, 3-7 September, Halle, Germany.

Reynaldi, F.J., Sguazza, G.H., Pecoraro, M.R., Tizzano, M.A., and Galosi, C.M. (2010) First report of viral infections that affect argentine honeybees. Environ Microbiol Rep 2 (6): 749-751.

Reynaldi, F.J., Sguazza, G.H., Tizzano, M.A., Fuentealba, N., Galosi, C.M., and Pecoraro, M.R. (2011) First report of Israeli acute paralysis virus in asymptomatic hives of Argentina. Rev Argent Microbiol 43: 84-86.

Rosenkranz, P. (1999) Honey bee (Apis mellifera L.) tolerance to Varroa jacobsoni Oud. in South America. Apidologie 30: 159-172.

Sheppard, W.S., Rinderer, T.E., Mazzoli, J.A., Steizer, J.A., and Shimanuki, H. (1991) Gene flow between Africanand European-derived honey bee populations in Argentina. Nature 349: 782-784.

Strauss, U., Pirk, C.W., Crewe, R.M., Human, H., and Dietemann, V. (2015) Impact of Varroa destructor on honeybee (Apis mellifera scutellata) colony development in South Africa. Exp Appl Acarol 65: 89-106.

Teixeira, E.W., Chen, Y., Message, D., Pettis, J., and Evans, J.D. (2008) Virus infections in Brazilian honey bees. J Invertebr Pathol 99: 117-119.

Tentcheva, D., Gauthier, L., Zappulla, N., Dainat, B., Cousserans, F., Colin, M.C., and Bergoin, M. (2004) Prevalence and seasonal variations of six bee viruses in Apis mellifera L. and Varroa destructor mite populations in France. Appl Environ Microbiol 70: 7185-7191.

Vetharaniam, I. (2012) Predicting reproduction rate of Varroa. Ecol Model 224, 11-17.

Yang, X., and Cox-Foster, D.L. (2005) Impact of an ectoparasite on the immunity and pathology of an invertebrate: evidence for host immunosuppression and viral amplification. Proc Natl Acad Sci USA 102: 7470-7475. 